
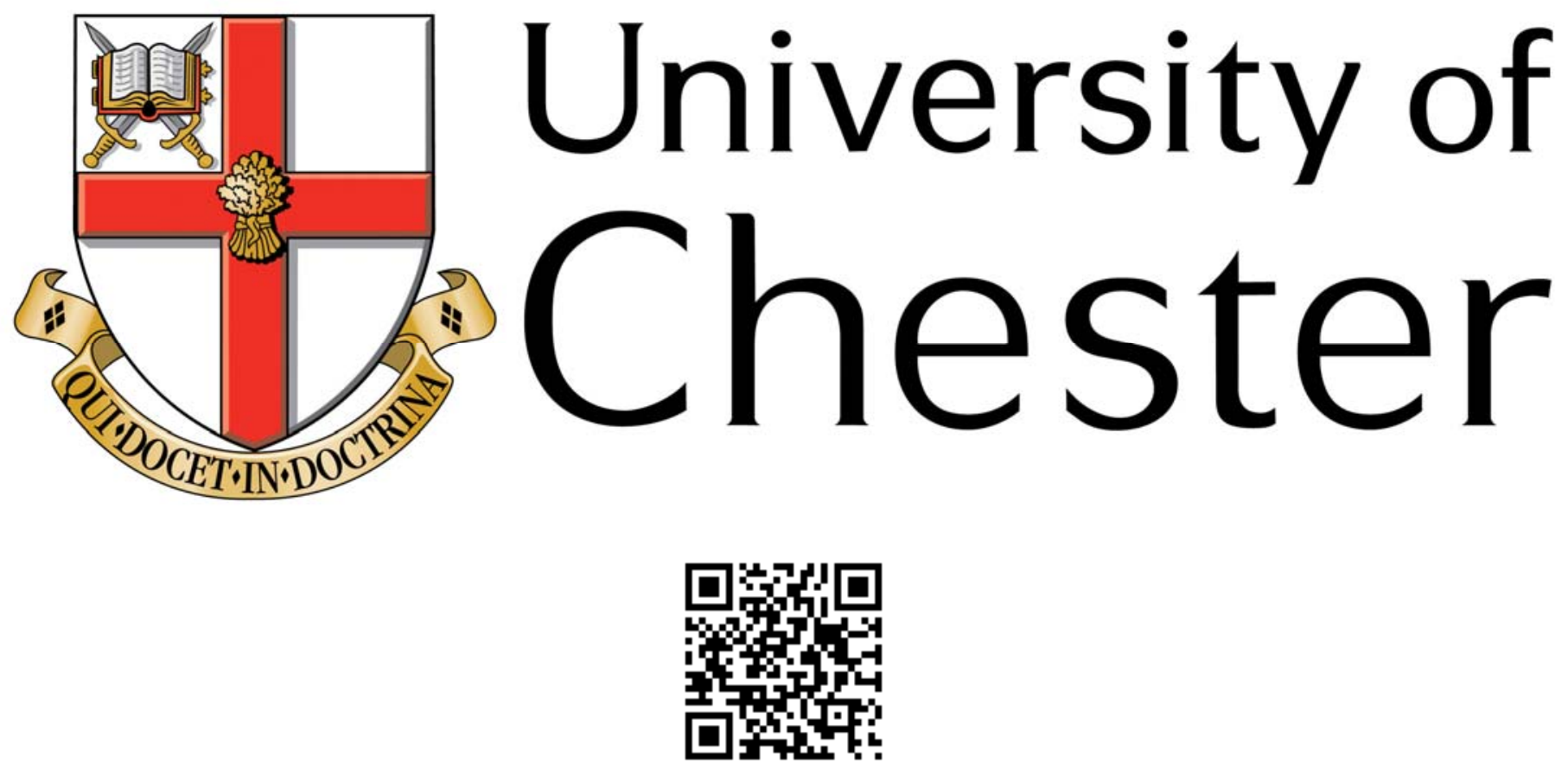

This work has been submitted to ChesterRep - the University of Chester's online research repository

\title{
http://chesterrep.openrepository.com
}

Author(s): Celia Deane-Drummond

Title: Futurenatural? A future of science through the lens of wisdom

Date: 1999

Originally published in: Heythrop Journal

Example citation: Deane-Drummond, C. (1999). Futurenatural? A future of science through the lens of wisdom. Heythrop Journal, 40, 41-59.

Version of item: Author's post-print

Available at: http://hdl.handle.net/10034/14689 


\section{FUTURENATURAL? A FUTURE OF SCIENCE THROUGH THE LENS OF WISDOM}

\section{CELIA DEANE-DRUMMOND University College, Chester, UK}

Traditional science looks to the future as part of its brief. It is looking inevitably forward to the new, to the discovery not yet anticipated, to the experiment that will test out a new idea. FutureNatural is a book that expresses this desire, but in a wider context of culture and society.(1) While the idea of 'nature' has shifted over the millennia, science now seems to be playing a leading role in carving out the kind of future that we can expect for the natural world. This book raises the question: does 'nature' have intrinsic value or is it simply a cultural construct? How can we tell the difference between a 'nature' that is real and one that is illusory, given the technological interventions now possible in science?(2) In particular, the modern biotechnological processes of genetic engineering of life forms seems to raise the question of whether we are justified in tampering with what are perceived as 'natural' relationships. Should we be alarmed by the way scientific models and theories are taken up and become cultural metaphors? Artificial life and artificial intelligence seem to mimic 'natural' life and intelligence in their potential for replication and problem solving.(3) Within the artificial life that is currently being envisaged, analogies to 'natural' life come through naming and the images created. However, artificial life is not just a simulation, it creates life as it could be.(4) Related to this idea is the concept that intelligence can be artificially propagated indefinitely. We therefore arrive at what Frank Tipler has called the 'physics of immortality'.(5)

What kind of future is envisaged by this new physics? It is one where the place of emotion, human engagement with values, religious and spiritual experience all seem to be obsolete. 
It is perhaps significant that one of the few references to religious themes in FutureNatural was a barbed tongue-in-cheek postscript called 'An Interview with Satan', where Satan took the guise of the author of the Enlightenment.(6) The absence of emotion and genuine human interaction is exemplified in electronic communications technology.(7) Mark Poster suggests that while modernism promotes practices that are autonomous and rational, electronic communications today are postmodern in orientation and promote subjects that are unstable, multiple and diffuse. Virtual communities are understood as having the attributes of real communities, but without the 'flaws' of the real. The natural is 'improved' through visual reality.

Other attempts at 'improving nature' are emerging in the rapidly developing field of New Genetics. However, in this case the philosophical assumptions of modernist culture still linger, even though the New Genetics is flowering in the soil of postmodern cybernetic structures. By New Genetics I am referring to the modern genetic technologies that have been applied to all life forms containing nucleic acids and their associated genetic components. When such technology has an applied, commercial focus it becomes a component of biotechnology. It seems to me that the underlying philosophy in this case is modernism, which contrasts with the postmodern undertones of the New Physics. None the less, some scientists strongly object to the way in which aspects of New Physics have been taken up by postmodern philosophers.(8) No such attempt has been made to incorporate the New Genetics into postmodern philosophy. While the underlying drive for progress in the New Genetics is a legacy of modernism, the increasing fragmentation of knowledge and the spiralling capacity to create forms outside species boundaries lead to a postmodern gloss on the enterprise. 
The history of science shows that, in a general sense, the cultural and political agenda fitted the particular way science was done. Hence the idea of fixed laws that were set up at the creation of the world formed the background to the thinking of early modern scientists. Isaac Newton and John Ray, for example, perceived God's will and wisdom in the laws of creation and the natural world.(9) Their success fitted in with the political agenda of the time. Stephen Toulmin suggests that after the collapse of the medieval feudal system a new cosmopolis emerged 'in which the divinely created order of nature and the humanely created order of society were seen as illuminating one another'.(10) Similarly, the Darwinism of the nineteenth century fitted in with the political ideal of progress.

The New Genetics, with its emphasis on the individual and commercial materialism, similarly fitted the early Thatcher years of government when everything seemed possible. The early press reports of the discoveries of genetic advance are almost always optimistic. It is only when these new findings are applied to particular cases that problems surface within practical contexts. Such swings from optimism to scepticism could serve to generate realism.

It seems fair to say that the public gave a mixed reception to the recent discovery that an animal can be cloned. Traditional dogma of science stated that only plant somatic cells had the potential to develop into adult plants. Scientists working for commercial agriculture began exploring the possibility that this may not be the case. lan Wilmut, working at the Roslin Institute in Edinburgh, discovered that it was possible to insert the genetic material of a donor sheep's somatic cell into an egg cell from another sheep that had its nucleus removed.(11) In most cases hybrid cells failed to survive. However, in a small fraction of cases an embryo developed, which was then implanted into a surrogate mother. In one 
case a normal lamb known as 'Dolly' developed, which was genetically identical to the donor sheep. What was not widely publicized was that the majority of lambs had various abnormalities, including many that were oversized, bringing considerable risk to the mother and lambs in question. It seems that after the first flush of success, there is a limited potential for this to be applied in any systematic way for commercial use. It is the genetically engineered cloned sheep known as 'Polly' that is of more interest in this respect, compared to the first cloned sheep 'Dolly'. 'Polly' is capable of producing, according to the most recent reports, sixty times the human blood clotting protein Factor IX compared to humans.(12) The vast resources that had been channelled into this project seem wasteful in retrospect as far as the companies are concerned. It seems to have led to shock waves and anxious fears amongst the public that such techniques might be applied to human beings. The dream of immortality takes shape in a different guise.

There is another possible reason for public disquiet in the face of these developments in new biology. The philosophical basis for genetics is related to a quest for certainty, for knowledge as power to control events. The commercialization of genetic screening and other patents for 'gene products' panders to the desire to know with certainty our future and the risk that we take in making certain decisions. However, the human desire to know beyond reasonable doubt is never really satisfied. All that genetic screening and testing can do is to point to probabilities, except in a small minority of cases. Does this mark a change in climate from the renaissance humanism of the early part of this century, which searches for a reintegration of humanity and 'nature' and a greater respect for the emotions?(13) The ambivalence in response is reflected in the fact that while, on the one hand, genetic window-shopping seems here to stay, on the other hand, there seems to be, if anything, a shift towards alternative therapies, a distrust of modern medicine or at least a 
scepticism about its value.

Toulmin suggests that we need to develop a cosmopolis that is suited to the culture of our time.(14) The hallmarks of this cosmopolis are 'diversity and adaptability', rather than the 'stability and uniformity' characteristic of Newtonian science. The overall basis for the new cosmopolis is the ecological motif, which, Toulmin suggests, encourages differentiation, diversity, equity and adaptability. However, does ecology necessarily lead to the kind of flexibility that he envisages? Those who have made ecology part of their political and philosophical agenda have run the risk of generating a new form of fascism which, according to Cheyney, bears some similarity to ancient Stoic philosophy.(15) Those involved in traditional science are unlikely to listen to a language of ecology because such language stirs up a memory of conflict and hostility. The molecular biologists won the battle for funding in the 70 s and 80 s, largely at the expense of ecologists. While there are signs that this is beginning to be reversed in the climate of greater awareness of the importance of environmental issues, the memory is still a bitter one.

This article seeks to explore an alternative motif that has a more specific theological basis, namely that of wisdom. Above all, I hope to show that wisdom language can be used in a metaphorical way to point to a future of creation. Through exploring a biblical and theological basis for wisdom a new theology of creation emerges, which is relevant to some of the pressing issues emerging through new advances in bio-science. Furthermore, by reformulating the future of creation in the light of wisdom, a future of science comes into view that resonates with the postmodern requirement for adaptability and diversity, but without forgetting the idea of distinction between humanity and the natural world. The long tradition of wisdom brings both a rootedness in historical perspectives and dynamic 
flexibility that serves to inform the relationship between God and the natural world. It seems to me that a measure of stability is a requirement in shaping perspectives for the future, particularly if we are to meet the ambivalence and anxiety associated with new explorations in science.

\section{WISDOM IN A THEOLOGY OF CREATION}

By tradition wisdom is associated with philosophy and also with science. Have modern philosophers of science forgotten this ideal? Midgely believes this to be the case, and that what we need now is a return to the wisdom of the ancients.(16) Hardy similarly recognizes a trend in the history of science where wisdom becomes separated from the transcendent ideal of Plato, limited to human rationality alone, but the extent to which the rise of modern science had to refer to a transcendent 'higher wisdom' is a matter of controversy.(17)

What is wisdom in theology? Is wisdom esoteric knowledge, granted to the few who obtain gnostic insight?(18) This form of wisdom grows more naturally out of a Greek tradition of wisdom, which focused on the development of ideal conditions for knowledge and the ordering of society.(19) This does not seem to be the main characteristic of the Hebrew tradition of wisdom, where materiality is ever present.(20) From a biblical perspective, wisdom is expressed in a number of different ways, including:

i) wisdom sayings, such as Proverbs 10-30;

(ii) theological wisdom, including speculative passages such as Proverbs 8; reflections on theodicy, such as the arguments in Job; reflections on fundamental questions of human identity, such as Ecclesiastes.

(iii) nature wisdom, exemplified by Job 28:38-42; Wisd 7:17-20; 
(iv) mantic wisdom, as in the book of Daniel, including divination and dream interpretation; and

(v) higher wisdom through revelation, including apocalyptic revelation.(21)

While there is a place in theology for mantic wisdom and higher wisdom through revelation, it is within the context of a long history of wisdom rooted in practical contexts. I will return to a discussion of apocalyptic literature later. My purpose here is to show how wisdom literature in general is rooted in a theology of creation and the implications of this for a contemporary creation theology. I would therefore suggest that there is a close relationship between type ii and type iii above.

It is only relatively recently that there has been a surge of interest in wisdom literature among Old Testament scholars. One of the reasons for this was the belief that salvation history was the kernel around which other themes should be fitted.(22) Westermann gives a more positive account of wisdom by locating it under the theme of blessing and creation, which is in dialectical relationship with soteriology and history.(23) He identifies the earliest wisdom tradition as centred on anthropology, the wisdom of the sages. The later tradition becomes cosmological in scope. Childs makes the provocative statement that 'As an essential witness to God's purpose in his creation, wisdom is built into the very structure of reality, and in this role seeks to guide humanity to the way of truth.'(24) Perdue argues that not only is wisdom theology grounded in creation, but also creation is at the centre of wisdom theology.(25) Wisdom themes can be organized around anthropology, cosmology or theodicy. In anthropology wisdom is the art of steering, applying knowledge to the experiences of life in a way that includes a 'fear' of the Lord. This 'fear' is not so much terror or religious experience of awe, but piety characterized by faith in God as the creator 
and sustainer of life. Wisdom values the human capacity to discern truth and celebrates human freedom. Wisdom is also described as a principle of order and justice, made concrete in wisdom and law. This anthropological thread is important in that it puts emphasis on the right relationship between humanity and the Creator, which is the basis for finding wisdom.

Perdue suggests that we need to examine the wisdom literature in ways that are more in keeping with its original intent.(26) If wisdom is portrayed in discursive language, this is at the expense of imagistic and aesthetic dimensions. Hardy's suggestion that the hermeneutic of Old Testament wisdom is that of praise hints at a similar dynamic movement in the wisdom tradition that prevents it becoming 'fixed' or 'substance like'.(27) The possibility that wisdom can portray creation theology through metaphor seems to me to be a fruitful one, since it has the ability to stir both reason and imagination while showing due respect for the apophatic tradition. Creation theology cannot compete with science at the level of detailed knowledge, but it can create images to help us to perceive creation in a way that is theologically consistent.

In Proverbs the metaphors used to describe the origin of the world are artistry, fertility, battle and struggle. For the sages, God uses wisdom to create and sustain the world. For example, Proverbs 3:13-20 speaks in the first strophe of the contentment of those who find wisdom. The second strophe uses language that elsewhere is applied to the deity, especially 3:17. The third strophe explores wisdom's role in the creation of the world. The pursuit of wisdom is not simply an intellectual exercise, but an anthropomorphized commitment of the heart where Wisdom is the object of human love and affection, such as Proverbs 1:20-33. Human life and well-being are thus grounded in creation. Wisdom 
seems to function as the artificer of creation. It is significant that this role of wisdom in cosmology is used to reinforce the role of wisdom in anthropology.(28)

Wisdom comes as divine gift, but it is also the result of human study and desire. While wisdom cannot be grasped, she cannot be attained without a thirst. The portrayal of creation as divine gift to humanity is rooted in the traditional interpretation of the relationship between God and creation as found in the Thomistic tradition.(29) However, wisdom is not confined to the human community; as artificer of creation it follows that wisdom is involved with all created beings.

Wisdom's place in creation is elaborated further in Proverbs 8. The interpretation of this passage has been the subject of scholarly controversy. Proverbs $8: 22 \mathrm{ff}$. suggests that wisdom is associated with the beginning of creation. However, the meaning of qānānî in 8:22 may imply possession by God or creation by God, especially when linked to the idea of a beginning.(30) Whatever the interpretation, close relationship between God and wisdom is implied. The actual role of wisdom in creation described in Proverbs 8:30 has proved difficult to decipher because of the ambiguity associated with the word 'āmôn in Proverbs 8:30a. The possible alternatives include wisdom as craftsman or, less likely, as foster child.(31) If the former sense is taken, then wisdom is intimately bound up with the creation of the universe reiterating the sense of $8: 26 \mathrm{~b}$ and $8: 29$, which imply that all of matter and all ordering comes about through wisdom. The final outcome of $8: 30 \mathrm{~b}$ is the celebration of this idea, that wisdom is also a source of joy, wonder and praise.

Ben Sira portrays Wisdom as an attribute of God, personified as female. Like the books of Job and Ecclesiastes, for Ben Sira wisdom is ultimately a mystery known only to God. All 
human strivings after wisdom are only partial reflections of the divine reality. As such, wisdom instils a spirit of humility that applies equality to theological reflections on creation. The opposite of wisdom is arrogance (Sira 10:7-22); hence it is through humility that humans are given the task of rulers of the earth.(32) It is significant that in the portrayal of an ideal king in Sira 10:3 there is a close link between kingship and wisdom, a theme also present in the Wisdom of Solomon (6:19). It is possible that the ideal of a wise ruler, which is also characteristic of Plato and the Stoics, exerted an influence on this literature.(33)

The replacement of arrogance by humility through wisdom is a theme worth pondering in the modern environmental context, including the commercialization of life through genetic patenting. Job 38 reminds the reader that the care of Yahweh for creation goes beyond concern for the welfare of human life. The metaphor of humanity as king over creation means that humanity has vice-regal responsibility over creation. However, there is no divine mandate for autonomous human rule over creation. There are always limits to the ability of humans to influence the earth. A recognition of such limits is one of the characteristics of traditional science.(34) In the light of the new possibilities now on offer in genetics, the challenge to science and technology goes even further than simply voluntary or legislated limits. Instead, a greater humility is called for so that biotechnology will direct its future in a way that is in tune with consequences for all of creation.

\section{WISDOM IN A THEOLOGY OF REDEMPTION}

Creation theology shaped by biblical wisdom would remain another utopian dream were it not for the judicial and salvific role of wisdom in the Old Testament that is articulated further in the New Testament. Von Rad argued that the early literature reflected on wisdom arising out of common experience, giving practical laws about human living, while in the 
post-exilic phase wisdom becomes God's call, a mediator of revelation, a divine principle permeating the world. This concept of development in sapiential literature in the way that von Rad envisaged has now been challenged.(35) None the less, it seems likely that the specific links between wisdom and the Torah are evident in later literature, even though creation theology relating to wisdom has always been present. Ben Sira, in identifying wisdom with the Torah, gathers Wisdom into the saving revelation of God. He 'is the first sage to bring sapiential teaching about creation into the normative traditions of Israelite faith that focused on salvation history'.(36) Wisdom is both the mist that covers the earth, but also the ruler of nations and peoples (Sira 24:1-7).(37)

The relationship between Christ and wisdom in the New Testament is a subject of much scholarly interest. Scott suggests that Jesus is portrayed as a teacher of wisdom in Q, which becomes adapted in Matt 23:34 and Lk 11:49 so that words attributed to Sophia are put in the mouth of Jesus. In this case Jesus fulfils the function of Sophia as the closest intimate of God.(38) Parallels between the origin and function of Logos and Sophia are characteristic of John's Gospel. For example, the role given to the Logos in the Prologue to John's Gospel echoes that of wisdom in Proverbs 8:22-23.(39) Both the Logos and Wisdom existed in the heavens before the world was formed and both share in the creative process. Scott argues further that the Logos is the means through which Christ becomes an embodiment of Sophia, since Logos was an established synonym for Sophia.(40) Dunn has explored the relationship between Christ, the cosmos and wisdom in Colossians. He notes that the body of Christ in Colossians has many layers of meaning, namely as the church, the body of Christ on the cross and the cosmos itself.(41) The church becomes a mirror or microcosm of the divinely ordered cosmos. Hence 'as the creative power of divine wisdom is now defined in terms of Christ, so the cosmos of divine 
purpose can (should) now be defined in terms of the church.'(42) The paradox of the claim of this early Christian community is 'that the wisdom behind and permeating the universe is most clearly seen and its character most clearly perceived in the cross'.(43)

The question now is this: has the role of wisdom become muted through identification with Christ, or is her place strengthened? Does the replacement of Sophia, a feminine term, with the Logos, a male term, reinforce patriarchal modes of thought as some feminist theologians have argued?(44) Fiorenza suggests that in the Gospels Jesus is not only identified with Wisdom, but that Jesus is a messenger and prophet of Sophia. She is sharply critical of the dominance of Father/Son language in John, which she believes excludes the idea of woman Wisdom:

The Fourth Gospel thereby not only dissolves the tension between the grammatical feminine gender of Sophia and the 'naturalised'] gender of Jesus, but also marginalises and 'silences' the traditions of God as represented by Divine Woman Wisdom.(45)

It seems to me that the ambiguous relationship between Sophia and Jesus/Logos remains one of tension and distrust as long as Wisdom is seen in narrowly Christological terms. The temptation to identify Sophia with Jesus in an exclusive sense or with the Virgin Mary is bound to be fraught with difficulties. Instead, identification of wisdom with the Trinity, in particular with the Holy Spirit, is a tradition that recovers images more in tune with the metaphorical language of the Old Testament.

The early Fathers of the church did not hesitate to ascribe wisdom to the Holy Spirit. Irenaeus, for example, distinguishes the task of the Word and Wisdom in the initial creative process: 
For with Him there were always present the Word and Wisdom, the Son and Spirit, by Whom and in Whom freely and spontaneously, He made all things, to Whom he also speaks, saying, 'let us make man after our image and likeness'.(46)

Citing the Wisdom of Solomon he makes the claim more explicit:

I have largely demonstrated that the Word, namely the Son, was always with the Father; and that Wisdom also, which is the Spirit, was present with Him, anterior to all creation.(47)

The work of the Spirit, and by implication Wisdom, is to give life, healing and restoring creation to the original state found in paradise.(48) Irenaeus was writing in a particular context where Gnosticism was rife, with its belief that Gnostics had the secret wisdom of God as expressed through their own esoteric practices and mysteries.(49)

Similarly Augustine of Hippo believed that the Spirit and Wisdom are identified, but wisdom is characteristic of all three persons:

I know not why both the Father and the Son and the Holy Spirit should not be called Love, all together one Love, just as both the Father and the Son and the Holy Spirit is called Wisdom, and altogether not three, but one wisdom. For so also both the Father is God and the Son God and the Holy Ghost God, and all three together one God.(50)

First Corinthians 1-3 identifies the wisdom of God with the gospel, but it is Trinitarian in shape: the wisdom of God, the wisdom of the Spirit and the wisdom of Christ are interconnected. The Corinthians believed that wisdom was a human possession, and in response Paul suggests that the wisdom he preaches is the 'word of the cross' (1:18); 'Christ crucified' (1:23); 'Christ the power of God and the wisdom of God' (1:24); 'Christ Jesus, whom God made our wisdom, our righteousness and sanctification and redemption' (1:30); 'the wisdom of God in a mystery' (2:7); 'words taught by the Spirit' (2:13). He 
suggests that his proclamation is the revealed wisdom of God (2:10). Hence wisdom encompasses not just the person and work of Christ, but 'the whole cosmic drama of God's creative sovereignty, justification of sinners, and redemption of the world'.(51)

The above suggests that the wisdom of God is not restricted to a theology of creation, but is a means through which creation and redemption can become linked. It seems to me essential to include a redemptive strand if reflection on the future of creation is to have any basis in reality, one which faces the sinfulness of the human condition, but within the context of wisdom understood as blessing derived from the Old Testament.

\section{WISDOM AND APOCALYPTIC LITERATURE}

For Old Testament scholars the initial idea that wisdom literature could be related to the apocalyptic tradition has proved to be something of an enigma. The contrast seems striking.(52) While for the ideal sage the meaning of life is immanent and is accessible through the present mundane experiences of the world, for the seer meaning is to be found in the future, the transcendent realm. A sage seeks meaning in proper conduct of life now, through social relationships, personal integrity and so on. By contrast, the seer seeks meaning in divine activity that will occur in the future. Wisdom is available to all who earnestly seek her, while for the seer revelations are given to the few from mysteries coming from another world. Commonly a sage expresses confidence in the order, harmony and balance of God's creation and the place of humanity within it, while the seer despairs of all order this side of the eschaton; there seems to be no justice meted out in this world.

The issue of relating wisdom to the apocalyptic tradition is complicated by the fact that the 
term apocalyptic, like eschatology, is a somewhat slippery, ill-defined category.(53) Christopher Rowland argues against conflating the two categories. While a popular interpretation of the eschatology of apocalypses could suggest that they point to a future that is ahistorical, it is significant that 'their authors expected a vindication of their righteousness within the world of men, not in some intangible existence beyond the sphere of history'.(54) Furthermore, the eschatological expectations within apocalyptical literature are neither uniform nor confined to this genre alone. Hence to use the term apocalyptic to describe a particular kind of eschatology is not really justified.(55) The possible connection between wisdom and apocalyptic becomes less surprising once apocalyptic literature is no longer perceived simply in terms of a particular eschatological framework. Overall both wisdom and apocalyptic literature concerned itself with problems of human existence in this world. In certain wisdom texts, such as Job, the answer to the problem of innocent suffering comes through divine revelation. Rowland concludes that wisdom is one of the constituents of apocalyptic literature, 'indeed probably the most important of all, the quest for knowledge and the belief that some answers at least could be found'.(56)

Stone explores the relationship between wisdom and apocalyptic literature through a detailed analysis of their parallel lists.(57) The subject matter of the apocalypses are catalogued through these lists. He notes that wisdom and the secrets of nature are included in the subject matter along with astronomy, meteorology, cosmology and uranography. Many elements of the lists present in 4 Ezra and 2 Baruch, for example, have their parallels in Job 28 and 38, especially with reference to creation themes. Stone also notes the presence of interrogative lists more often associated with wisdom literature. For example, the form of rhetorical questions, which pose the inaccessibility of Wisdom and the greatness of Wisdom, found in passages such as Sira 8:4-5 or Wisd 9:13-18, is 
also expressed in 2 Baruch 14:8-9. A similar passage is found in 4 Ezra 4:10-11.(58) These examples support Rowland's conclusion that there is an integration of wisdom language and ideas into apocalyptic literature.

Stone notes an even more striking development in 1 Enoch 93:11-14, where rhetorical questions about wisdom are replaced by rhetorical questions about the heavenly secrets. However, the context of this passage is one where, in 1 Enoch 93:10, the elect will receive 'sevenfold instruction concerning all His creation'.(59) Stone believes that this implies that the possibility of such knowledge of the heavenlies does exist, but only the righteous will receive it. He argues that both the form and the language of wisdom have been reinterpreted and reused for the purposes of the apocalyptic writing. In this case at least, wisdom is invested with a new meaning. The unknowability of creation, as expressed in the wisdom literature, is now proclaimed as accessible to the seer through divine revelation.

Additional examples of an interweaving of strands of wisdom and apocalyptic ideas can be found in the New Testament. Romans 1:18-32, for example, is apocalyptic in speaking of the divine wrath anticipated for those who refuse to acknowledge God. Their claim to be wise is confounded by their wickedness.(60) Wisdom is again portrayed in an apocalyptic guise in the book of Revelation. In this case wisdom is revelation. The secrets of the end time are revealed, but for a purpose, so that appropriate action can be taken.(61) In 5:12 and 7:12 hymns are sung to the throne of wisdom, but only God and the Lamb are worthy recipients of wisdom. Pippin suggests that the personification of Sophia in different figures of mother of the Messiah, the Son of man and the Spirit results in Sophia's disempowerment. However, it seems to me that Sophia, in being identified with God, 
Jesus and the Spirit, shows herself to be of divine origin. The idea that the feminine in God refers to all persons of the Trinity and should not be confined to the Holy Spirit has been argued convincingly by Sarah Coakley.(62) A Trinitarian concept of Sophia allows her to become the feminine face of God.(63)

\section{A FUTURE OF SCIENCE THROUGH THE LENS OF WISDOM}

The above reflection on the development of the biblical uses of wisdom shows that Wisdom as a metaphor is a complex term; it challenges and is provocative in many different aspects. I intend here to demonstrate that once the goal of science is shone through the refractive lens of wisdom, many different colours appear depending on the particular face wisdom presents. There is no one future of science that is compatible with theological wisdom, but many futures. Wisdom acts like a guide, rather than a fixed predetermined goal to be achieved. The particular mode of wisdom that is relevant in each case will depend on particular issues under discussion. By drawing on examples from the biological sphere of science I hope to show how wisdom is of relevance in delineating future science policy and practice.

\section{(a) Contemplative wisdom}

Contemplation of the natural world is one way in which one might interpret wisdom. The basic tenet of this mode of wisdom is that of natural theology, namely that it is through close observation of the natural world that God can be discovered. Examples of such contemplative forms of wisdom abound in the accounts of creation in most wisdom literature, such as Wisd 7:17-22. How far is such a practice relevant to the way humanity treats the natural world? Does creation spirituality, which this implies, lead to pantheism? This seems more likely when the shadowy side of creation and its need for redemption is 
ignored. As I will show below, the contemplative aspect of wisdom needs to be balanced with recognition of a need for redemption. One strand that is especially relevant for the future of science is the way contemplative wisdom encourages the capacity to wonder. If we lose this capacity for experiencing the glory of creation as it is, then we lose the ability to love creation and treat it with the respect that it deserves as a gift of God.

Another way in which we can view contemplative wisdom is through contemplation of God, rather than the natural world. In this case our understanding of wisdom is one that echoes the ultimate Wisdom of the Godhead. Its closest biblical derivative is the revelation experienced by John in the book of Revelation, or the mantic wisdom of Enoch or Daniel. Hildegard of Bingen presents us with some striking examples of how she perceived Wisdom in the order of nature, but in the context of a vision of reality.(64) Such visions were not all positive affirmations of the natural world, she was only too well aware of the darker side of creation. Sergius Bulgakov was at pains to point out that Sophia was both creaturely and divine, thereby retaining the distinction between God and creation.(65) He has been accused of pantheistic tendencies. None the less, it is clear that he intended to maintain the distinction between God and creation.(66)

These ideas are significant in that they show how the search for Wisdom goes beyond rational discussion and moves into the arena of mystery. Paradoxically, it can lead to the same overall effect as the normative theology of the book of Ecclesiasticus, namely a sense of proportion and humility towards our own strivings after wisdom. The wisdom that we discern in practical situations can be tested in the fire of contemplative prayer. The wisdom that humanity seeks to attain is always partial, which expresses the fundamental truth that I mentioned at the beginning of this article, namely that wisdom is ultimately a gift 
that is given, rather than an object to be grasped.

\section{(b) Judicial wisdom}

One of the hallmarks of the wisdom literature is a strong emphasis on justice, but in most cases the assumption is that justice will be done through the power of God's righteousness. The book of Job is a notable exception that challenges the idea that we can find justice in this life. The story of Job, which tells of a man broken by misfortune and loss, leads to his despair. He eventually falls silent in his attempt to understand God. Job's struggle to find meaning in an unjust world finally leads to his recognition of the action of God in the wildest and most remote places of the earth. He never finds a final answer to his question: where can justice be found?

The book of Ecclesiastes is similarly sceptical about the justice of God. The author challenges the equation of righteous living with well-being and life. He also rejects the involvement of God in the natural rhythms of the universe. Whybray argues that it is incorrect to assume that the natural cycles are portrayed as futile; rather, they simply show regularity.(67) Qoheleth's radical rejection of all natural theology, which is finding God in the natural world, empties the world of divine purpose. New discoveries become mere selfdeceptions, whereby a sense of collective and individual identity is lost. For Qoheleth the sovereignty of God is grounded in power rather than justice; the experience of reality remains thoroughly enigmatic. Wisdom is limited in the world predetermined by fate. The supreme gift for Qoheleth is the gift of joy, but even this is a gift bestowed in an apparently random way by God.(68)

While Qoheleth seems to foster a view of the world which regards all human striving as 
'absurd', there are threads here worth considering in the present context. While both Job and Qoheleth doubt the existence of God's justice, Job wrestles with God and is given an answer from the whirlwind. The sheer weight of global injustice, especially in the field of biotechnology, which is biased heavily in favour of the richer Western nations, might lead to the sense of absurdity expressed in Ecclesiastes. For example, more funding is allocated to discovering the way strawberries can be engineered to withstand frost conditions than is spent on the improvement of basic subsistence crops grown in the Third World, such as cassava, beans or maize.(69)

A ray of hope from this lens of wisdom is that it keeps all human endeavours in perspective. The idea that there is 'nothing new under the sun' reminds us that all our efforts are dependent on others. Science is built up from the work of communities, even though individuals may make the final breakthrough. This came out through the reports of the research that led to the cloning of sheep; it was the combined efforts of many minds that led to the final discovery. It is false to lay the blame of any such developments at the door of the discoverer. In this case the scientists believed that knowledge is there to be found. If they had not made the breakthrough, some other research group would have done so. It is disturbing that the BBC documentary Horizon, which reported these developments to a national audience, used images and music from church and choral settings.(70) It was as if science, through its technological advance, becomes a form of religious experience and is thereby baptized as good.(71) What the producers failed to recognize was the principle of justice: is it just for so many sheep to be sacrificed for the sake of scientific research? Is it just to spend many millions of pounds on work that will have only very tenuous benefits for a narrow sector of the population and will in all probability only benefit the few with vested interests? Is such action respectful to the sheep 
as having integrity before God, and have we developed this in tune with the creature's own interests at heart? Ethical outcomes of a particular practice are being discussed only now, after the event has taken place. There seems to be insufficient scrutiny of the ethical 'committees' that are supposed to act as a filter for new developments.(72) We seem to be caught in a situation where those who might best challenge such practices are marginalized or ignored.

God sharing in human suffering, weakness and death in the person of Jesus, as Jürgen Moltmann has argued, finally puts an end to any misconception of God as tyrant.(73) The future that we can look forward to is one where justice prevails. Wisdom both in the Old and New Testaments reminds us that it is our duty to perform acts of justice here and now. The promise of the future kingdom gives hope in spite of human failure to reach these goals. Wisdom is therefore expressed as dynamic involvement, but is also realistic. As Moltmann suggests, we need to resist the temptation to fall back into despair or escape into utopia, but live instead in realistic hope.(74)

\section{(c) Feminine wisdom}

The figure of Woman Wisdom in Proverbs, Ecclesiasticus and the Wisdom of Solomon comes to us in various feminine disguises. For example, in Proverbs we have the Queen of Heaven (e.g., Proverbs 8), Goddess (e.g., Proverbs 3), counterfoil to Woman Folly (e.g., Proverbs 9). Whether or not she is a divine hypostasis or a personification of a divine attribute, the idea of the feminine somehow shaping our search for wisdom seems here to stay.(75)

The wisdom of the sage shares some affinity with feminist theology in that both are in most 
cases rooted in practical, experiential knowledge. However, like contemplative wisdom, feminine wisdom has an immanent and a transcendent pole. In the transcendent pole Wisdom appears as Woman Wisdom, a Goddess, the Queen of Heaven of the Old Testament. In the immanent pole, Woman Wisdom is practical, grounded in the daily tasks of life. I have argued elsewhere that the Goddess pictured in the Old Testament is not a separate being or hypostasis of God.(76) Rather, Sophia is the feminine face of God as expressed in all persons of the Trinity. Rather than confine the feminine to the Holy Spirit, or the Virgin Mary, as in traditional dogma, the feminine, as Coakley suggests, becomes characteristic of the Godhead in Trinitarian relationships.(77)

What does this mean for the future of science? There is increasing evidence that the way women conduct science is subtly different from that of men. While early women scientists succeeded by 'aping men', modern science is still 'curiously silent on the issue of gender'.(78) Feminist approaches to science 'do not simply supplement existing approaches and methods. They carry the potential to unbalance the status quo, and to change radically the most deep rooted beliefs about our scientific history.'(79) Women are beginning to rewrite the history of science, in much the same way that feminist theologians are rewriting the biblical accounts of the Christian story. Bleier suggests that interaction and concern with process is characteristic of women's ways of knowing, whereas beliefs in objectivity, neutrality and dualistic thinking characterize science moulded by male thinking.(80)

What is the contribution of feminine wisdom to these debates? It seems to me that feminine wisdom refuses to become the privilege of a few, but is serving her purpose when integrated into the existing structure. A mere replacement of objective knowledge with 
process leads to other difficulties. Instead, just as feminine wisdom is part of a Trinitarian divine, so science needs to be open to alternatives, without necessarily expecting a radical replacement of one by the other. In some circumstances a process model works best, whereas in others it is the traditional model. At this point we need to call on the other quality of wisdom, namely wisdom as discernment.

(d) Wisdom as discernment

Wisdom as discernment is the practical wisdom of the sage. The choice is held up between contrasts - Wisdom or Folly - yet it is clear that the wisdom of God can at times seem like folly to human beings. The relationship, then, is not necessarily an obvious one, especially in the light of the Christian gospel. However, the ability to make choices characterizes science today and we must face up to crucial decisions. How far should we be allowed to become co-creators with God in engineering crops and animals for our food? How far should we take transgenic experimentation, especially that relating to human beings? Should there be a moratorium on all human cloning? How do we distinguish one research project from another in terms of its likely risk and benefit for humanity and the earth? Who is responsible for measuring these risks? In order to begin to answer such questions we need a well-developed sense of wisdom as discernment. Aquinas argued that such discernment comes through the action of the Holy Spirit.(81)

\section{CONCLUSION}

The ever-increasing possibilities before us through the technology of modern science, in particular the New Genetics, seem set to continue. The future of the natural world, including humanity, is at stake once we ponder the likely impact of these developments. I have argued here that the theological tradition of wisdom can act as an appropriate guide 
through the labyrinth of possibilities. While the traditional understanding of wisdom in the Old Testament is rooted in creation theology and concerned with present decisions, wisdom in the New Testament develops the idea still further that wisdom cannot be based on human insight alone. I have tried to show how the theme of creation and redemption in the biblical wisdom literature reminds us that wisdom is a gift from God that can affirm creation as well as liberate it from bondage to sin. Traditional scholarship has placed apocalyptic in the prophetic stream of literature, in contrast to the wisdom literature. However, this rigid dichotomy does not do justice to the way wisdom and apocalyptic are in some cases interwoven. Thus there are some biblical precedents for including wisdom in theological reflection about the future. Furthermore, wisdom serves to keep consideration of the future grounded in the practical, without losing sight of the glory and beauty of the Wisdom of the Trinity. The many faces of wisdom serve as an appropriate metaphor in a postmodern age that is resistant to monolithic interpretations of the future. A future of creation emerges that is conscious of the realities of the present, but also points to a future hope that gives due credit to the feminine face of God. Such a metaphorical way of thinking is not hostile to all science, but helps to place it in a wider cultural contextual history. Wisdom serves to challenge some of those presuppositions of the New Genetics that seem to weaken the value of human and non-human creation under the mask of 'improving' nature.

\section{Notes}

1 G. Robertson, M. Mash, L. Tucker, J. Bird, B. Curtis and T. Putman (eds.), FutureNatural: Nature, Science, Culture (London: Routledge, 1996).

$2 \quad$ Ibid., 'Introduction', pp. 1-4; K. Soper, 'Nature/"nature" ‘, pp. 22-34.

3 Ibid., N. K. Hayles, "Narratives of Artificial Life', pp. 146-64.

4 Ibid., M. Poster, 'Postmodern Virtualities'], pp. 183-202. Some practitioners go as far as saying that 'artificial life' is not just a simulation process, but life itself. In this case, however, the genotype merges with the phenotype. In other words, these artificial forms are themselves capable of evolutionary processes. Furthermore, humans now have the ability to define what they become; ibid., T. Terranova, 'Posthuman Unbounded: Artificial 
Evolution and High-Tech Subcultures', pp. 165-80.

$5 \quad$ F. J. Tipler, The Physics of Immortality: Modem Cosmology, God and the Resurrection of the Dead (Basingstoke: MacMillan, 1994).

6 F. Dexter, 'An Interview with Satan', in Robertson et al. (eds.), FutureNatural: Nature, Science, Culture, pp. 293-302.

7 Poster, 'Postmodern Virtualities'.

8 For example, the recent controversial book Impostures intellectuelles by Jean

Bricraont and Odile Jacob suggests that the way the theories are used by philosophers to embellish their ideas is, quite simply, farcical from a scientist's point of view. See A. Sokel and J. Bricmont, 'The Naked Postmodernists', The Times Higher Educational Supplement 10 October (1997), pp. 22-3.

9 See, for example, J. Ray, The Wisdom of God Manifested in the Works of Creation (London: W. Innys and R. Manby, tenth edn, 1735); C. E. Raven, John Ray: Naturalist; His Life and Works (Cambridge: Cambridge University Press, 1942).

10 S. Toulmin, Cosmopolis: The Hidden Agenda of Modernity (New York: The Free Press/MacMillan Inc, 1990), p. 98.

11 D. King, 'Sheep Cloning Furore Misses the Real Issues', GenEthics News 11 (March/April 1996); pp. 1, 3; D. King, 'Sheep Cloning Sparks World Furore', GenEthics News 16 (January/March 1997), pp. 1, 10. See also, D. King, 'Animal Cloning Charges Forward', GenEthics News 19 (August/September 1997), pp. 1-2.

12 'Science Report', The Independent 4 March (1998).

13 Toulmin, Cosmopolis, pp. 159-62.

14 Ibid., pp. 183-5.

15 J. Cheyney, 'The Neo-Stoicism of Radical Environmentalism', Environmental Ethics 11 (1989), pp. 293-326. In addition, ecological science is a subversive science, which seeks to revolutionize the basis for modern scientific method. See, G. Hardin, 'Ecology and the Death of Providence', Zygon 15 (1980), pp. 57-68.

16 M. Midgley, 'Strange Contest: Science versus Religion' in H. Montefiore (ed.), The Gospel and Contemporary Culture (London: Mowbray, 1992), pp. 40-1. Midgley argues that the remit of what science is has shrunk in modern times, especially in the thought of specialists, but the idea that science still has a key place in shaping the rest of thought still prevails. M. Midgley, Science as Salvation: A Modern Myth and its Meaning (London: Routledge, 1992), pp. 1-15.

17 D. Hardy, 'Rationality, the Sciences and Theology' in G. Wainwright (ed.), Keeping the Faith: Essays to Mark the Centenary of Lux Mundi (London: SPCK, 1989), pp. 284-8. 18 This seems to be the position taken by Artuur Versluis in his TheoSophia: Hidden Dimensions of Christianity (Hudson: Lindisfarne Press, 1994).

19 Hardy, 'Rationality, the Sciences and Theology', p. 290.

20 Ibid., p. 291.

21 J. Collins, 'Wisdom, Apocalypticism and Generic Compatibility' in L. G. Perdue, B. B. Scott, W. J. Wiseman (eds.), In Search of Wisdom: Essays in Memory of John G. Gammie (Westminster: John Knox Press, 1993), p. 168.

22 G. von Rad, for example, acknowledged that creation had a central place in wisdom literature, but such dominance of creation themes seemed to imply a lack of distinction from surrounding fertility cults. G. von Rad, 'Some Aspects of the Old Testament World View' in E. W. Trueman Dicken (trans.), The Problem of the Hexateuch and Other Essays (London: Oliver and Boyd, 1966), pp. 144-65. See also G. von Rad, Wisdom in Israel (London: SCM Press, 1972).

23 C. Westermann, Genesis 1-11: A Commentary, trans, J. Scullion (London: SPCK, 1984); C. Westermann, Blessing in the Bible and the Life of the Church (Philadelphia: 
Fortress, 1978).

24 B. Childs, Old Testament Theology in a Canonical Context (Philadelphia: Fortress, 1985), p. 35.

25 L. G. Perdue, Wisdom and Creation: The Theology of the Wisdom Literature (Nashville: Abingdon Press, 1994), p. 34.

26 Ibid., p. 48.

27 Hardy, 'Rationality, the Sciences and Theology', pp. 292-3.

28 For example, Perdue, Wisdom and Creation, states that 'In this image of the divine architect, wisdom is the skill, plan and knowledge God uses to secure and order the cosmos, depicted as a great building with pillars (mountains; Job 26:11; Psalm 18:7) to support the sky and with a foundation constructed over the cosmic ocean. Subsequently wisdom continues to bring stability to the ongoing cosmic order. In the embrace of Wisdom (i.e. the knowledge and actualization of sapiential teaching), the student embodies the same cosmic power of life and knowledge that God used in creating and governing reality' (p. 83).

29 Schmitz draws on Aquinas's idea of creation as 'endowment' or 'gift'; it is 'absolute reception' or 'sheer receiving'. A gift has a non-obligatory, unexpected character, while receiving is not passive but attentive; we have to be available in order to receive. Risk is attached to the receiving as it opens up the significance of the gift. He suggests that we have lost the art of being receptive through our determination to be autonomous. K. L. Schmitz, The Gift: Creation, The Aquinas Lecture, 1982 (Milwaukee: Marquette University Press, 1982), pp. 33-56.

30 Whybray comments that in Proverbs 8:22-26 no less than five words are used denoting the temporal priority of wisdom before creation came into being. The term qānānî in 8:22 describes the manner in which Yahweh brought wisdom into existence and can mean 'created', 'possessed', 'begot', or 'acquired'. Whybray suggests that while 'acquired' is the basic meaning, the context suggests either 'created me' or 'begot me', understood in a metaphorical way. The most important point is that wisdom comes first and is followed by metaphors of birth in subsequent verses. Kidner, however, prefers 'possessed' for qānānî. R. N. Whybray, Wisdom in Proverbs (London: SCM Press, 1965), pp. 99-100; D. Kidner, Proverbs, D. J. Wiseman (ed.), Tyndale Old Testament Commentaries (Leicester: The Tyndale Press, 1964), pp. 79-80.

31 Some scholars, such as Whybray, prefer the translation 'craftsman', or 'skilled worker'; see Whybray, Wisdom in Proverbs, pp. 100-1. Others, such as Perdue, prefer the term 'little child', Wisdom and Creation, p. 91; however the term 'foster child' seems a more likely alternative in this context. See also R. E. Clements, Wisdom in Theology (Exeter: Paternoster, 1992), pp. 114ff.

32 For further discussion of the theme of wisdom personified as female in Ben Sira, see Perdue, Wisdom and Creation, p. 249. For discussion of the admonition against human arrogance in Sira ch.10, see pp. 258. Subsequent chapters, especially 17:3-7, speak of the way wisdom allows humanity to rule over creation in a manner that is honouring to God; see pp. 259-61.

33 R. Murray, The Cosmic Covenant (London: Sheed and Ward, 1992), p. 142. Murray also notes that the portrayal of humanity as rulers over creation in the second creation account in Genesis similarly suggests that humanity displays the kingly quality of wisdom in relationship to the animals, which is a feature that is also recorded by Philo (p. 100).

34 P. Medawar, The Limits of Science (Oxford: Oxford University Press, 1986).

35 von Rad, Wisdom in Israel. For a discussion see Perdue, Wisdom and Creation, pp. 23-5.

36 Perdue, Wisdom and Creation, p. 262. 
Ibid., p. 271.

38 M. Scott, Sophia and the Johannine Jesus (Sheffield: Sheffield Academic Press, 1992), pp. 85-6.

39 Ibid., p. 96. Similar links with other Psalms can be found, such as Psalm 103:24 or Psalm 71.19 (see p. 101). Scott arrives at the conclusion that 'the Logos of the Prologue is none other than Sophia', p. 113.

40 Ibid., pp. 93, 114.

41 J. D. G. Dunn, 'The Body in Colossians' in T. E. Schmidt and M. Silva (eds.), To Tell the Mystery: Essays in Honour of Robert H. Gundry (Sheffield: Sheffield Academic Press, 1994), pp. 63-81, especially p. 174.

42 Ibid., p. 175.

43 Ibid., p. 180.

44 E. A. Johnson, She Who Is: The Mystery of God in Feminist Theological Discourse (New York: Crossroad, 1994).

45 E. S. Fiorenza, Jesus: Miriam's Child, Sophia's Prophet (London: SCM Press, 1995), p. 153.

46 Irenaeus 1, in A. Roberts and J. Donaldson (eds.), translated by A. Roberts and W. Rambaut, Ante-Nicene Library: Translations of the Writings of the Fathers down to AD 325, Volume V (Edinburgh: T. \& T. Clark, 1874), IV.20.2, p. 439.

47 Ibid., IV.20.4, p. 440.

48 Irenaeus 11, in ibid., Volume IX (Edinburgh: T. \& T. Clark, 1875), V.12.6, p. 86.

$49 \mathrm{H}$. Urs von Balthasar, trans. by J. Saward, The Scandal of the Incarnation: Irenaeus against the Heresies (San Francisco: Ignatius Press, 1990), p. 30.

50 Augustine, Volume VI: On the Trinity, in M. Dods (ed.), The Works of Aurelius Augustine, Bishop of Hippo (Edinburgh: T. \& T. Clark, 1873), XV.27.28, pp. 412-13.

51 E. E. Johnson, 'The Wisdom of God as Apocalyptic Power' in J. T. Carroll, C. H. Cosgrove and E. E. Johnson (eds.), Faith and History: Essays in Honour of Paul W. Meyer (Atlanta: Scholars Press, 1990), p. 147.

52 E. E. Johnson, The Function of Apocalyptic and Wisdom Traditions in Romans 9-11 (Atlanta: Scholars Press, 1989), pp. 70-1.

53 For a sharp critique of the use of terminology see T. F. Glasson, Jesus and the End of the World (Edinburgh: St Andrew's Press, 1980). Also relevant is J. Carmignac, Le Mirage de l'eschatologie (Paris: Letouzey et Ané, 1979).

54 C. Rowland, The Open Heaven (London: SPCK, 1982), p. 38.

55 Rowland, The Open Heaven, p. 26-9, also p. 37.

56 Ibid., p. 208. Rowland critiques von Rad's suggestion that wisdom is a source for apocalyptic literature. However, while there is little evidence for a developmental link, there is a relationship between both types of literature. See p. 204 and G. von Rad, Old Testament Theology 2: The Theology of Israel's Prophetic Traditions, trans. D. M. G. Stalker (Edinburgh: Oliver \& Boyd, 1965), pp. 306-8.

57 M. E. Stone, 'Lists of Revealed Things in the Apocalyptic Literature' in F. M. Cross, W. E. Lemke and P. D. Miller (eds.), Magnolia Dei: The Mighty Acts of God, Essays on the Bible and Archaeology in Memory of G. Ernst Wright (New York: Doubleday \& Co., 1976), pp. 414-52.

58 Ibid., pp. 421-3.

59 Ibid., pp. 425; for general discussion of the significance of this passage, see pp. 423-6.

60 E. Johnson, 'Wisdom and Apocalyptic in Paul' in Perdue, Scott and Wiseman (eds.), In Search of Wisdom, p. 273.

61 T. Pippin, 'Wisdom and Apocalyptic in the Apocalypse of John' in Perdue, Scott and 
Wiseman (eds.), In Search of Wisdom, pp. 285-95.

62 S. Coakley, 'Femininity and the Holy Spirit?' in M. Furlong (ed.), Mirror to the Church: Reflections on Sexism (London: SPCK, 1988), pp. 124-35.

63 C. Deane-Drummond, 'Sophia: The Feminine Face of God as a Metaphor for an EcoTheology', Feminist Theology 16 (1997), pp. 11-31.

64 B. Newman, Sister of Wisdom: St Hildegard's Theology of the Feminine (Berkeley: University of California Press, 1987).

65 S. Bulgakov, Sophia: The Wisdom of God: An Outline of Sophiology (Hudson: Lindisfarne Press, 1993).

66 C. Andronikof, 'La Problématique sophianique', Le Messanger Orthodoxe 98 (1985), pp. 46-7. See also B. Newman, 'Sergius Bulgakov and the Theology of Divine Wisdom', Saint Vladimir's Theological Quarterly 22 (1988), pp. 39-73.

67 R. N. Whybray, 'Ecclesiastes 1:5-7 and the Wonders of Nature', Journal for the Study of the Old Testament 41 (1988), pp. 105-12.

68 L. G. Perdue, Wisdom and Creation pp. 225-42.

69 K. Dahlberg, New Directions for Agriculture and Agricultural Research (Lanham: Rowman and Allanheld, 1986). For further discussion, see C. Deane-Drummond, 'Genetic Engineering for the Environment: Ethical Implications of the Biotechnology Revolution', HeyJ 36 (1995), pp. 307-27.

70 BBC2 Horizon, 'Dawn of the Clone Age', 23 October (London: British Broadcasting Company, 1997).

71 For discussion, see M. Midgley, Science as Salvation, pp. 1-15.

72 D. King, 'Ethics Committees Everywhere', GenEthics News 19

(August/Septemberl997), p. 2. ;

73 J. Moltmann, The Crucified God (London: SCM Press, 1974). ;

74 J. Moltmann, Theology of Hope (London: SCM Press, 1967), pp. 22-6. .

75 C. Deane-Drummond, 'Sophia: The Feminine Face of God', pp. 11-31. See other articles in this special issue on Sophia, Feminist Theology 16 (1997), especially N. E. Beckman, 'Sophia; Symbol of Christian and Feminist Wisdom?', pp. 32-54.

$76 \quad$ Ibid., p. 12-18.

77 Coakley, 'Femininity and the Holy Spirit?'. Coakley includes a useful discussion of the idea of the 'feminine', arguing that the prefix 'traditionally' assigned to females should allow the notion of the 'feminine' to be inclusive, rather than exclusive, pp. 130-2.

78 L. Schitbinger, The Mind Has No Sex: Women in the Origins of Modern Science (Cambridge: Harvard University Press, 1989), p. 8.

79 M. Benjamin, Science and Sensibility: Gender and Scientific Enquiry 1780-1945 (Oxford: Blackwell, 1991), p. 17.

80 R. Bleier, Science and Gender: A Critique of Biology and its Theories on Women (Oxford: Pergamon Press, 1984), pp. 197-202.

81 J. Mahoney, Seeking the Spirit: Essays in Moral and Pastoral Theology (London: Sheed and Ward, 1982); see especially chapters on 'The Spirit and Moral Discernment in Aquinas', pp. 63-80; 'The Spirit and Community Discernment in Aquinas', pp. 81-96. 